\title{
TEXTURE PROFILE PROPERTIES, SENSORY EVALUATION, AND SUSCEPTIBILITY TO SYNERESIS OF YOGHURT PREPARED FROM LACTOSE-FREE MILK
}

\author{
Zs. KÁRNYÁCZKI ${ }^{\mathrm{a} *}$ and J. CSANÁDI ${ }^{\mathrm{b}}$

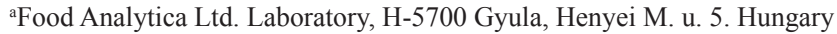 \\ ${ }^{b}$ University of Szeged, Faculty of Engineering, H-6724 Szeged, Moszkvai krt. 5-7. Hungary
}

(Received: 7 March 2016; accepted 29 June 2016)

\begin{abstract}
Milk and dairy products are high-value foods; however, consumers suffering from lactose intolerance are not able to enjoy the nutritional benefits of these commodities. There are more and more researches and developments focusing on lowering the lactose content of milk and dairy foods in order to make them available for lactose intolerant people. In this study, we examined the coagulation time, product quality, texture profile properties, and syneresis of yoghurts prepared from lactose-free milk. Significant differences were observed between the control and lactose-free milks with respect to coagulation time and texture profile. The first rupture time, the hardness, and the adhesion force of the lactose-free yoghurt were higher compared to the control product. We observed remarkable difference between the whey leakage of control and lactose free yoghurt samples $(21.47 \%$ and $14.63 \%)$. Results coming from instrumental texture profile analyses showed that the preliminary lactose hydrolysis of milk resulted a firmer texture. It was confirmed by the results of sensory evaluation, and considering the texture and taste, there was significant difference between the control and lactose-free yoghurts.

Keywords: yoghurt, lactose-free, coagulation time, texture profile, whey leakage
\end{abstract}

Milk is rich in bioactive substances; they contain essential proteins and amino acids, remarkable amount of minerals, valuable carbohydrates and vitamins. Milk and dairy products have a number of health-related benefits: their components have anti-cancer and cancer prevention effects, they help digestion and healthy bowel function and they also have a major role in preventing arteriosclerosis and osteoporosis (LAAKSONEN et al., 2009; WILT et al., 2010).

Of all dairy foods, cultured milks may have the widest variety of nutritional benefits. Nowadays, an increasing number of consumers enrich their diets with vitamins, minerals, or dietary fibres (e.g., prebiotics) and add probiotics or use them as starters to produce tasty functional foods with a pleasant flavour (VARGA et al., 2006; SZAKÁLY, 2011; CASAROTTI et al., 2014). Lactose intolerance (affecting almost $70 \%$ of the world's population) obstructs milk consumption (PAIGE, 2005). Milk produced by mammals serves to feed the offspring for a certain period, differing by species. Most of the people do not consume milk in adulthood. The lactase activity may be decreased; the gene which is responsible for the enzyme production can become inactive. These conditions affect more than $70 \%$ of the population worldwide; more than $90 \%$ is Asian and African countries (BuLHÕES et al., 2007). Therefore, more technological developments focus on removing or lowering lactose content from milk.

\footnotetext{
* To whom correspondence should be addressed.

Phone: +36 66 321-016; fax: +36 66 547-430; e-mail: karnyaczkizsuzsanna@gmail.com
} 
Lactose is extractable from milk by both physical and chemical ways. During ultrafiltration, milk is forced through a defined pore size membrane at a sufficiently high pressure dividing it into two fractions. Lactose can thus be removed as permeate, but other valuable nutrients are removed as well (RAGHUNATH \& HiBBARD, 1997).

During enzymatic hydrolysis, $\beta$-galactosidase is added to the milk, which breaks down the milk sugar to its monomers. Because of the glucose and galactose, the lactose-free milk is noticeably sweeter compared to regular milk (CSAPÓ \& CSAPÓNÉ, 2002). Lactose hydrolysis rate of $70 \%$ equals $2 \%$ of sucrose regarding milk sweetness (ZADOw, 1986).

First, KosIKоwSKI (1979) used ultrafiltered milk concentrate for yoghurt making after protein and fat standardization $(3.3-4.6 \%$ and $1.4-2.6 \%)$. The lactose level of the final yoghurt was $0.48-0.63 \%$.

SZIGETI and co-workers (2006) developed a manufacturing technology for the production of lactose-free yoghurts using a two-step fermentation process. They extended the duration of fermentation to 6 hours by neutralizing the lactic acid formed with sodium- and potassiumhydroxide. Thus, lactose fermentation by the yoghurt starter organisms was not inhibited by the increasing rates of lactic acid. IBARRA and co-workers (2012) worked out a technology for low-lactose probiotic yoghurt. Lactose was decomposed by $\beta$-galactosidase $\left(1 \mathrm{ml} \mathrm{kg}^{-1}\right)$ and then Lactobacillus rhamnosus HN001 and a conventional yoghurt culture (Streptococcus thermophilus and Lb. delbrueckii ssp. bulgaricus) were added to produce lactic acid.

Further aspect is to decrease the galactose content of hydrolysed milk - considering the galactose intolerance - by the use of different mixture of Lactobacillus and Streptococcus subspecies (ANBUKKARASI et al., 2014.)

Fermented milk products have an extremely sensitive protein matrix (curd) that mostly depends on the composition of raw milk, but it is also affected by the homogenization, pasteurization, composition of substrate, culture varieties, and incubation temperature (VÉLEZ-Ruiz, 2008; SchmidT et al., 2016).

It is hard to maintain a consistently good yoghurt quality, because it is sensitive to technological and compositional changes. Certain components of milk must be enriched or reduced in a way that preserves the product's natural properties and enjoyment value. The food industry must keep pace with the ever-increasing expectations of consumers, who demand low-fat foods rich in dietary fibres and vitamins that do not contain added sugars. These demands can only be met with continuous developments and innovations.

Therefore, the objective of this research was to examine the effects of preliminary lactose hydrolysis during the manufacture of lactose free yoghurt. Nowadays, the lactose hydrolysis is a daily routin in dairy technolgy, but we need detailed information about the effects of hydrolysis on the technology and on the special product properties as texture properties of set type fermented milk products. Much data can be found on the texture of traditional yoghurts (VÉLEZ-RuIz, 2008; ILIČćć et al., 2013; KARSHEVA et al., 2013). Therefore, the investigations related to the water binding capacity of curds, the ratio of syneresis, the clotting time of milk, and the changes in sensory properties would be possible.

\section{Materials and methods}

Production and storage of the experimental fermented milks was carried out in the dairy laboratory of the Faculty of Engineering of the University of Szeged. Raw cow's milk (protein: $3.32 \%$; fat: $3.75 \%$ ) of the same origin was heated at $75{ }^{\circ} \mathrm{C}$ for $5 \mathrm{~min}$, cooled to 
$60{ }^{\circ} \mathrm{C}$, and then homogenized at a pressure of $20 \mathrm{MPa}$ (APV Gaulin Lab 60, Lab Merchant Limited, London, UK). Half of the milk was used as control, and into the other half of milk Maxilact 2000 enzyme at $0.2 \%$ (v/v) (DSM Food Specialties B.V. Delft, the Netherlands) was added. After that, every technological step was the same. Milk samples were placed in an incubator at $40{ }^{\circ} \mathrm{C}$ for $1 \mathrm{~h}$. Lactose level was measured with a refractometer (RFM712; VWR International Kft., Debrecen, Hungary). The lactose concentrations of the samples treated with lactase were lower than $0.5 \%(\mathrm{w} / \mathrm{v})$ in all cases. Milks were inoculated with a YoFast 88 freeze-dried DVS culture (Chr. Hansen, Hørsholm, Denmark), a mild flavored culture with a high viscosity and a fast acidification time, containing Lactobacillus acidophilus and Bifidobacterium along with Streptococcus thermophilus and L. delbrueckii ssp. bulgaricus, at the rate of $0.1 \mathrm{~g} / 5$ litres milk. Following inoculation, parallel samples were prepered in $100 \mathrm{ml}$ centrifuge tubes for the measuring of whey separation. These samples were subsequently treated the same way as the other milks and dairy products. The inoculated milk was packed into cups (Junior Handy; Zootechnika Kft., Gödöllö, Hungary) and was incubated at $45^{\circ} \mathrm{C}$ in an incubator until reaching a pH value of 4.6. Acidity was continuously monitored with an Orion 4 Star Plus pH-meter (Thermo Scientific, Singapore). At pH 4.6, the yoghurts were cooled to $5{ }^{\circ} \mathrm{C}$ and were stored for $24 \mathrm{~h}$.

Instrumental tests were done to determine the texture profile of the samples and to examine the curd hardness difference between the control and lactose-free yoghurts. The instrumental examination was carried out with a QTS 25 texture profile analyser (CNS Farnell, Hertfordshire, UK), and data were processed using the Pro Texture software package. It measures the forces occurring during intrusion and extrusion with a probe, and it also records the time. By moving the probe up and down, the force occurring in the cell changes due to the sample's resistance and texture. Actually, a typical penetration test was performed. The applied parameters during the structure analyses were as follows:

$\begin{array}{ll}\text { Type of examination: } & \text { Texture profile analysis (TPA) } \\ \text { Probe diameter: } & 12 \mathrm{~mm} \\ \text { Probe movement speed: } & <1000 \mathrm{~mm} \mathrm{~s}^{-1} \text {, with an interval of } 1 \mathrm{~mm} \mathrm{~s}^{-1} \\ \text { Speed accuracy: } & \text { Better than } 1 \% \text { of the whole scale } \\ \text { Penetration depth: } & 20 \mathrm{~mm} \\ \text { Maximum force: } & 2500 \mathrm{~N} \\ \text { Sample size (diameter/depth) } & 65 \mathrm{~mm} / 120 \mathrm{~mm}\end{array}$

For syneresis measurements, special $100 \mathrm{ml}$ plastic tubes containing yoghurt samples (50-50 g each) were centrifuged with a High Speed Brushless Centrifuge (MPW-350 MPW Med. Intruments. Inc., Poland) at $300 \mathrm{~g}$ for $2 \mathrm{~min}$. Separated whey was removed and then weighed to four decimal places accuracy with an Ohaus Explorer analytical balance (Ohaus, Budapest, Hungary). Syneresis rate was expressed in terms of percentage.

Sensory evaluation was carried out by a 6-member panel, using a 20-point rating scale divided by 0.5 points. The following organoleptic properties were assessed: texture, colour, smell, and taste. They were each graded on a scale ranging from 1 (worst) to 5 (best). The whole process was in accordance with the requirements laid down in Codex Alimentarius Hungaricus (2009) and in Hungarian Standard (1975).

Statistical analyses were carried out using SPSS for Windows, Version 13.0. The variance of data homogeneity was checked with the Levene test. In case of homogeneous and non-homogeneous variances, a double sample $\mathrm{T}$ test and a Welch test were done, respectively. Significance of difference was set at $\mathrm{P}<0.05$ in all cases. 


\section{Results and discussions}

\subsection{Changes in coagulation time}

The rate of coagulum formation was considerably lower in the lactose-free material than in the control milk (Fig. 1).

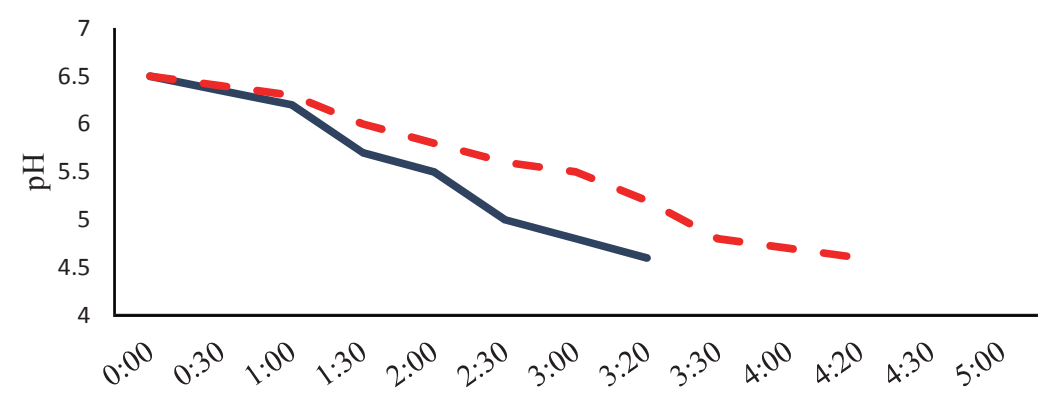

Elapsed time from inoculation, $\mathrm{h}$

Fig. 1. Changes in the $\mathrm{pH}$ of products $(\mathrm{n}=3)$. ___ C Control yoghurt; _ _ _: lactose-free yoghurt

The $\mathrm{pH}$ of the control product was an average of 4.77 after $3 \mathrm{~h}$ of incubation, whereas the $\mathrm{pH}$ of the lactose-free yoghurt was only 4.99 at the same time. The difference between the treatments was visible, by this time the coagulum strength of the control product almost reached the desired level, meanwhile the texture of the lactose-free yoghurts was still weak, almost fluid. The $\mathrm{pH}$ of the control and experimental products reached the value of 4.6 after $205 \mathrm{~min}$ and $261 \mathrm{~min}$ of incubation, respectively. Our results showed that the use of $0.2 \%$ Maxilact 2000 enzyme extended the coagulation time by an average of $1 \mathrm{~h}$. The significantly longer coagulation time of the lactose-free products could be explained by the delayed start of lactic acid production. A possible explanation would be the actual lower growing rate of Streptococcus termophilus (ST) during the first stage of fermentation in our experiments. SFAKIANAKIS and TzIA (2014) presented the cooperation of ST and Lactobacillus bulgaricus (LB), namely intensive lactase enzyme production of ST is necessary for lactose hydrolysis and then LB is able to rapidly produce lactic acid from glucose.

IBARRA and co-workers (2012) published similar results during the process development of low-lactose yoghurt with Lactobacillus rhamnosus HNO0. They demonstrated that lower initial lactose content increased fermentation time. VÉNICA and co-workers (2014) also confirmed slightly longer coagulation time of lactose-hydrolysed milk. Whereas NAGARAJ and co-workers (2009) and MATIJEVIC and co-workers (2011) reported opposite results. NAGARAJ and co-workers (2009) report an average of 35 minutes shorter fermentation time using different pre-hydrolysis ratio of milk. They explained it by the appearance of monosaccharides in milk coming from lactose hydrolysis.

\subsection{Texture profile analyses}

When evaluating the quality of yoghurt, one of the most important aspects to be considered is textural properties. In this study, four texture profile parameters were measured: first rupture force, hardness, adhesive force, and adhesiveness.

Acta Alimentaria 46, 2017 
First rupture force is the force necessary for the probe to overcome the flexibility of the coagulum and to rupture it (as a spoon ruptures the curd). Due to the breakdown of lactose, the necessary force significantly increased compared to the control product (Table 1). The values of the control product show very large differences, which can be explained by the discharge of whey. The texture profile analyser captures the first rupture force when the probe crosses the surface of the product. If syneresis occurs, the probe first penetrates the whey instead of the coagulum and, thus, the values vary widely.

Table 1. Texture profile of yoghurts

\begin{tabular}{lccrcrrrr}
\hline & $\begin{array}{c}\text { First rupture force } \\
(\mathrm{g})\end{array}$ & \multicolumn{2}{c}{$\begin{array}{c}\text { Hardness } \\
(\mathrm{g})\end{array}$} & \multicolumn{2}{c}{$\begin{array}{c}\text { Adhesive force } \\
(\mathrm{g})\end{array}$} & \multicolumn{2}{c}{$\begin{array}{c}\text { Cohesiveness } \\
(\mathrm{g} \times \mathrm{sec})\end{array}$} \\
\cline { 2 - 9 } & \multicolumn{1}{c}{$\mathrm{C}$} & \multicolumn{1}{c}{$\mathrm{LF}$} & \multicolumn{1}{c}{$\mathrm{C}$} & $\mathrm{LF}$ & $\mathrm{C}$ & $\mathrm{LF}$ & $\mathrm{C}$ & $\mathrm{LF}$ \\
\hline Mean & $10.00^{\mathrm{a}}$ & $35.57^{\mathrm{b}}$ & $106.80^{\mathrm{a}}$ & $120.68^{\mathrm{b}}$ & $-55.23^{\mathrm{a}}$ & $-72.89^{\mathrm{b}}$ & $-34.98^{\mathrm{a}}$ & $-42.8^{\mathrm{b}}$ \\
Minimum & 6.00 & 2.00 & 68.00 & 101.00 & -99.00 & -119.00 & -65.32 & -79.46 \\
Maximum & 35.00 & 56.00 & 124.00 & 134.00 & -7.00 & -31.00 & -2.55 & -14.21 \\
SD & 5.39 & 22.14 & 13.45 & 6.62 & 19.40 & 23.49 & 13.17 & 14.33 \\
\hline
\end{tabular}

C: control; LF: lactose-free

a,b: Means within the same texture profile parameter with different lowercase superscripts differ significantly $(\mathrm{P}<0.05), \mathrm{n}=90$

Hardness is the force needed to disrupt the structure of the product. Actually, this is the force necessary to press a spoon into the yoghurt. The low SD value of lactose-free yoghurts compared to the control indicates a product with more stable, more even, homogeneous structure.

Adhesion force is the force needed to remove the spoon in order to beat the adhesion of the coagulum. Adhesion force is correlated with hardness. The two products also differed significantly $(\mathrm{P}<0.05)$ in this attribute. The high adhesion force of lactose-free yoghurt indicates its strong and solid texture.

Cohesiveness is the area under the curve describing the penetration cycle of the probe. In other words, it is the force required to remove the adherent material from the surface. Based on our results, the reduced cohesiveness of the control yoghurts compared to the lactose-free products also suggests that the preliminary lactose hydrolysis of milk results more solid yoghurt texture.

Summarizing, there were significant differences $(\mathrm{P}<0.05)$ between the control and lactose-free yoghurts in all four texture profile parameters measured. The texture of lactosefree yoghurts was more solid and harder compared to our conventional yoghurts.

Contrary results are published by NAGARAJ and co-workers (2009), where the preliminary lactose hydrolysis of milk resulted in worse texture properties. The penetration of probe into yoghurt increased from 195 to $395 \mathrm{~mm}$ as the level of lactose hydrolysis increased from 0 to $90 \%$.

\subsection{Whey discharge analyses}

By analysing the degree of whey discharge, we aimed at determining the susceptibility of lactose-free yoghurt to water binding capacity (and syneresis), which is an important sensory attribute from the consumer's point of view. 
Lactose hydrolysis resulted significantly $(\mathrm{P}<0.05)$ lower whey discharge than the values of control samples (lactose-free yoghurts: $14.40 \pm 27 \%$ and control samples: $25.24 \pm 6.48 \%$ ). Improved water binding capacity caused by lactose hydrolysis is highly desirable in yoghurt making, it can increase the consumer's acceptance of the final product, and it can support the longer shelf-life as well.

Our result does not match the result of NAGARAJ and co-workers (2009), where the amount of whey separation increased as the degree of lactose hydrolysis increased.

\subsection{Sensory analyses}

The panelists gave a mean total score of 19.2 to the control yoghurt and 18.5 to the lactosefree product. No difference was found in odour and smell between the products. The colours of both yoghurts were evenly white and free from any discolouration, and they had a pleasant sour smell typical of yoghurts. The lactose-free product, however, tasted considerably sweeter than the conventional natural yoghurt. The results of sensory tests are summarised in Figure 2.

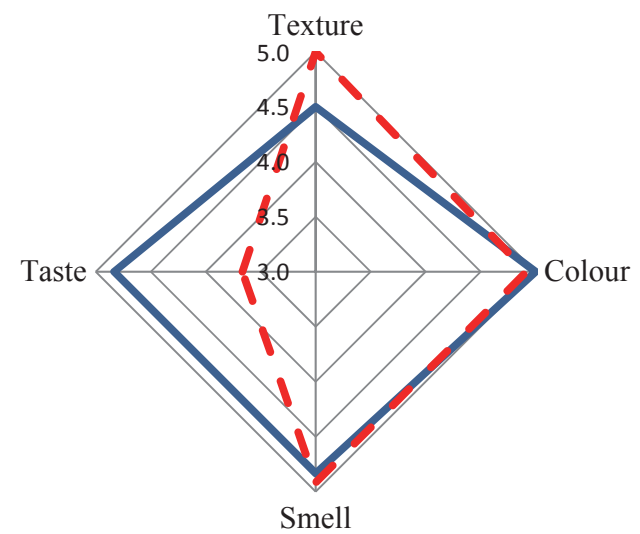

Fig. 2. Sensory properties of control and lactose-free yoghurts ( $\mathrm{n}=6)$. _. Control yoghurt; _ _ _: lactose-free yoghurt

As shown in Figure 2, significant differences $(\mathrm{P}<0.05)$ were found in both texture and taste between the two products. Our findings from texture profile analyses, which indicated that the texture of lactose-free yoghurt was more solid than that of the control product, were confirmed by the results of sensory evaluations. Similar publications detail the lactose-free products are sweeter than standard products (HILGENDORF, 1981; ZADOW, 1986), but these publications did not point out the harder texture of lactose-free yoghurt.

\section{Conclusions}

Preliminary hydrolysis of lactose in milk results in noticeable changes in coagulation time, textural properties, and sensory attributes of yoghurt. Extended coagulation time does not cause technological problems; however, the taste of yoghurt is negatively influenced by the 
absence of lactose in the raw material. In contrast, other organoleptic properties of the lactosefree yoghurt are superior to those of conventional natural yoghurts. Because of the increased sweetness of lactose-free milk, the quantity of sugar added to make commercial flavoured yoghurts may largely be reduced and, thus, even healthier cultured dairy foods can be manufactured from lactose-hydrolysed milk.

\section{References}

Anbukkarasi, K., Uma Maheswari, T., Hemalatha, T., Kumar Nanda, D., Singh, P. \& Singh, R. (2014): Preparation of low galactose yogurt using cultures of Gal+Streptococcus thermophilus in combination with Lactobacillus delbrueckii ssp. bulgaricus. J. Food Sci. Tech., 51, 2183-2189.

Bulhões, A.C., Goldani, H.A.S., Oliveira, F.S., Matte, U.S., Mazzuca, R.B. \& Silveira T.R. (2007): Correlation between lactose absorption and the C/T-13910 and G/A-22018 mutations of the lactase-phlorizin hydrolase (LCT) gene in adult-type hypolactasia. Braz. J. Med. Biol. Res., 40, 1441-1446.

Casarotti, S.N., Carneiro, B.M. \& Penna, A.L.B. (2014): Evaluation of the effect of supplementing fermented milk with quinoa flour on probiotic activity. J. Dairy Sci., 97, 6027-6035.

Codex Alimentarius Hungaricus (2009): 1-3/51-1 számú elöirás a tejtermékekröl, B rész (Regulation on milk products No 1-3/51-1, article B), pp. 9-10.

CsAPÓ, J. \& CSAPÓNÉ KISS, Zs. (2002): Tej és tejtermékek a táplálkozásban (Milk and milk products in human nutrition). Mezőgazda Kiadó, Budapest, Hungary, pp. 301-318.

Hilgendorf, M.J. (1981): Optimization of fungal lactase levels in yoghurt manufacturing. Cult. Dairy Prod. J., 16, $5-7$.

Hungarian Standard (1975): Joghurt (Yoghurt) no. MSZ 12258-75.

Ibarra, A., Acha, R., Calleja, M.T., Chiralt-Bois, A. \& Witting, E. (2012): Optimization and shelf life of a low lactose yogurt with Lactobacillus rhamnosus HN001. J. Dairy Sci., 95, 3536-3548.

Iličić, M.D., Milanović, S.D., Carić, M.Đ., Vukić, V.R., Kanurić, K.G., Ranogajec, M.I. \& Hrnjez. D.V. (2013): The effect of transglutaminase on rheology and texture of fermented milk products. J. Texture Stud., 44, $160-168$

Karsheva, M., Paskov, R., Tropcheva, R., Georgieva, R., Danova, S. (2013): Physicochemical parameters and rheological properties of yoghurts during the storage. J. Chem. Tech. Metallurgy, 48, 483-488.

Kosikowski, F.V. (1979): Low lactose yogurts and milk beverages by ultrafiltration. J. Dairy Sci., 62, 41-46.

Laaksonen, M.M.L., Mikkala, V., Rasanen, L., Rontu, R., Lehtimaki, T.J., Viikari, J.S.A. \& Raitakari, O.T. (2009): Genetic lactase non-persistence, consumption of milk products and intakes of milk nutrients in Finns from childhood to young adulthood. Brit. J. Nutr., 102, 8-17.

Matijevic, B., Lisak, K., Bozanic, R. \& Tratnic, L. (2011): Impact of enzymatic hydrolysed lactose on fermentation and growth of probiotic bacteria in whey. Mljekarstvo, 61, 154-160.

Nagaraj, M., Sharanagouda, B., Manjunath, H. \& Manafi, M. (2009): Standardization of different levels of lactose hydrolysis in the preparation of lactosehydrolyzed yogurt. Iran. J. Vet. Res., 10, 132-136.

Paige, D.M. (2005): Lactose intolerance. -in: Caballerco, B., Allen, L. \& Prentice, A. (Eds) Encyclopedia of human nutrition, $2^{\text {nd }}$ ed. Elsevier, Oxford, UK, pp. 113-120.

Raghunath, B. \& HibBard, D.C. (1997): Ultrafiltration of cooled milk. US Patent 5,654,025.

Schmidt, C., Mende, S. \& Rohm, H. (2016): Fermented milk products: effects of lactose hydrolysis and fermentation conditions on the rheological properties. Dairy Sci. Technol., 96, 199-211.

Sfakianakis, P. \& TZIA, C. (2014): Conventional and innovative processing of milk for yogurt manufacture; development of texture and flavor: A review. Foods, 3, 176-193.

SzakÁly, Z. (2011): Táplálkozásmarketing (Nutrition marketing). Mezőgazda Kiadó, Budapest, Hungary, pp. $194-202$.

Szigeti, J., KRÁsz, Á. \& VARGA, L. (2006): A novel technology for production of lactose-free fermented milks. Milchwissenschaft, 61, 177-180.

VARGA, L., Szigeti, J. \& Gyenis, B. (2006): Influence of chicory inulin on the survival of microbiota of a probiotic fermented milk during refrigerated storage. Ann. Microbiol., 56, 139-141.

VÉlez-Ruiz, J.F. (2008): Rheological properties of yogurt. -in: CAntor, J.M. (Ed.) Progress in food engineering research and development. Nova Sience Publishers, New York, NY, pp. 223-242. 
Vénica, C.I., Perotti, M.C. \& Bergamini, C.V. (2014): Organic acids profiles in lactose-hydrolyzed yogurt with different matrix composition. Dairy Sci. Technol., 94, 561-580.

Wilt, T.J., Shaukat, A., Shamliyan, T., Taylor, B.C., MacDonald, R., Tacklind, J., Rutks, I., Schwarzenberg, S.J., Kane, R.L. \& Levitt, M. (2010): Lactose intolerance and health. Evid. Rep. Technol. Assess. (Full. Rep.), 192, 410 pages.

Zadow, J.G. (1986): Lactose hydrolysed dairy products. Food Technol. Aust., 38, 460-462, 471. 